Selcuk Journal of Agriculture and Food Sciences

$\underline{\text { http://sjafs.selcuk.edu.tr/sjafs/index }}$

Research Article
SJAFS

(2019) 33 (3), 163-174

e-ISSN: 2458-8377

DOI:10.15316/SJAFS.2019.170

\title{
The Approaches of the Contracting Companies to the Housing Landscape in Konya Province*
}

\author{
Bahadır EKİCi ${ }^{1, *}$, Ahmet Tuğrul POLAT ${ }^{1}$ \\ ${ }^{1}$ Selçuk University, Faculty of Agriculture, Department of Landscape Architecture, Konya, Turkey
}

\begin{tabular}{l}
\hline ARTICLE INFO \\
\hline Article history: \\
Received date: 08.07 .2019 \\
Accepted date: 23.07.2019 \\
\hline Edited by: \\
Duran YAVUZ; Selçuk University, \\
Turkey \\
Reviewed by: \\
Sertaç GÜNGÖR; Selçuk University, \\
Turkey \\
Iş1k SEZEN; Atatürk University, Turkey \\
Keywords: \\
Housing \\
Residential Landscape \\
Landscape Project \\
Lanscape Applications \\
Contractor Company \\
\hline
\end{tabular}

\section{Introduction}

Cities are formed and shaped as a result of people's needs and desires in historical time periods and then they change and develop. The modern and social community of the present century has also endeavored to realize its desire to live in a comfortable, peaceful place and environment at the highest level (Kırgizoğlu, 1995).

The conceptual integration of the city and the landscape is formed by considering the structures together with the surroundings (Keleş, 2008). The streets, squares and parks in the city shape the displacement of people. These dynamic areas are important complements of work and home life in providing mobility, creating communication nodes, creating common spaces for recreation (Carr\&friends, 1992).

It can be said that people's interest and love for concepts such as nature, garden and tree stems from their own creation and self. Because of this reason, human beings have a positive attitude when they inter-

\footnotetext{
*This study was produced from Master's thesis of Bahadır EKİCI

* Corresponding author email: atpolat@selcuk.edu.tr
}

\begin{abstract}
Today's residences show highly functional and qualified formations and offer my functions to their users. One of the most important factors that increase opinions and experiences of the contractor companies that have implemented n the first part of the questionnaire, the approaches to projecting the housing end the factors that affect the project process are questioned. In the application stages, quality and characteristics of the application are presenting of 97 company officials show a positive approach to constructing andscape projects. In addition, 49 company officials stated that the effectiveness of the landscape in housing prices is high and very high.
\end{abstract}

act with plants and plant areas, whether they are aware or not (Polat\&Önder, 2012). Nature increases social cohesion and interaction among neighbors by encouraging the use of outdoor spaces (Chiesura, 2004). In a study conducted by the universities of Chicago and Illinois, it was found that the degree of development of social ties within the neighborhood was proportional to the level of vegetation (Sherer, 2003).

The housing sector constitutes a very important part of the construction sector. Housing has had a very important place in people's lives since ancient times (Gül, 2012). Today, when the housing need is examined, its infrastructure and transportation have been completed; social facilities such as education, health, culture and trade are sufficient; parks, gardens, landscaping, sports, recreation and entertainment facilities that offer contemporary living opportunities to people living in residential areas is understood (Bayraktar, 2007).

Residential gardens are becoming an important element for housing manufacturers as the contractor firms aim to act in line with the supply and demands of their customers. It is important for the contractors to increase their needs and responsibilities on the landscape and to consciously continue their projects and applications. 
In this study; the opinions and experiences of the contractor companies that have implemented housing projects in line with the supply and demands of the users have been determined. A survey was conducted through face to face interviews with 97 house producer company officials affiliated to Konya Contractors Association. In the first part of the questionnaire, the approaches to projecting the housing landscape and the factors that affect the project process are questioned. In the second part, landscape application approaches, various professional groups in the application stages, quality and characteristics of the application are presented. In the third section, the economic and financial evaluations of the residential landscape are made and the values that the landscape adds to the housing through projects and applications are determined. In the last part of the questionnaire, the satisfaction levels of the contractors and their customers were measured based on the experience of the contractors.

\section{Residential Landscape Projects and Applications}

Architecture and various design activities are seen as a link between people and the environment that is constantly changing. These design elements are the most important remnants of human activities from the past to the present. (Per\&friends, 2013). Nowadays, the dwellings built away from the known dwelling type are transformed into structures which give importance to the exterior appearance, offer many opportunities to the user and become an expression of social status (Edwards\&friends,2005). Residential units are architectural structures in which the freedom of creation within the design itself can be ensured (Broto, 2000). In the residential area, the garden serves as the social center of the family and it is also seen as the place where various guests can be accommodated (Song\&friends,2011). Residential landscape areas constitute the smallest unit of green areas. Gardens of single or multi-storey houses, terraces and roof gardens, balcony arrangements are evaluated within this unit. At this level, the building and the garden are integrated. It is generally defined as front, side and back garden. Its size, functions and aesthetic activities play an important role in relation to the cultural and economic status of the landlords as well as the physical and social characteristics of the city (Gül and Küçük, 2001).

In the landscaping works, the implementation of the landscape design process in the stages from the design to the implementation of the project is necessary in order to reach the needs, ecological priority, qualified, functional and aesthetic standards in urban areas and provide the expected benefits from these areas (Şişman\&friends2008; Polat and Önder, 2012). The finalization of the design process with a viable product can be achieved by monitoring and synthesizing the steps in the design process (Çınar, 2008).

These stages begin with the acceptance of the proect construction by the user or the employer and the creation of the site layout plans. Then, a survey about the area where the landscape project will be carried out inventories are collected within the scope of the study. These inventories are covered by topography, soil structure, climate data, vegetation, land use, landscape damages and infrastructure. After the field inventories are collected, project analysis is performed within the scope of this information and data. In the vicinity of these studies, the preliminary project should be created together with the stain studies in line with the thoughts and wishes of its users. The function studies carried out at all these stages need to be transformed into form in the final project formation. In the last stage of the application project, structural and plant elements are completely solved and the landscape project is terminated according to the finest details and features in terms of technical aspects.

Landscape architecture is in a basic relationship with the environment. The places where the landscape will be applied have their own features. Landscape areas are generally damaged or empty areas from pre ious activities. Landscape applications in these areas contribute to the environment, but can also bring nega ive results in wrong applicaions (Smith\&friends, 2008).

Landscape applications are carried out in various stages of herbal and structural. These are shaped like application of the project, construction of structural elements, irrigation installation, lighting installation, soil reclamation, plant material planting, planting grass and garden equipment, etc.

\section{Materials and Methods}

\subsection{Materials}

The main material of this research is constituted by the Konya Chamber of Commerce and the contractor firms which work in the field of housing construction affiliated to Komüt (Konya Contractors Association) (Figure 1). Graduate theses, scientific researches, books and related literature were used to form the theoretical foundations of the research. Survey forms were designed to determine the approach of the contractor firms towards the housing landscape. SPSS 22 software was used in the statistical analyzes to be applied to the findings obtained from Microsoft Office software during the writing phase. Chamber of Commerce and Konya Contractors Association data's, satellite pictures for information, zoning plans, aerial photographs and so on materials provided. In addition, cameras, voice recorders were used in the study. 

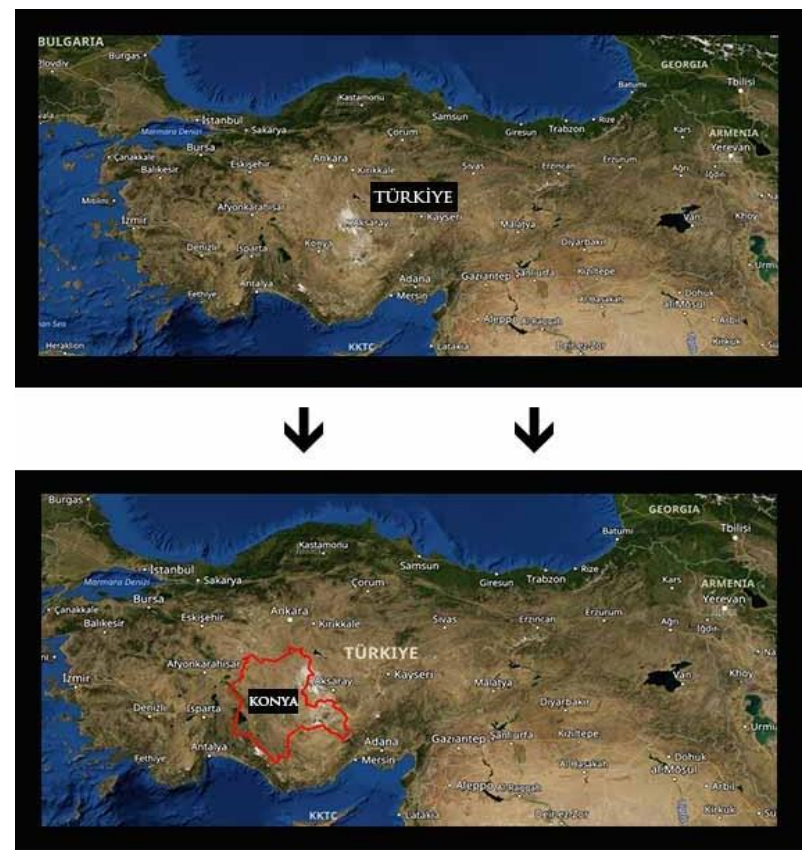

Figure 1

Location of the Research Area

\subsection{Methods}

The method of the study was carried out in three stages. In the first stage, after determining the purpose and scope of the study, theoretical foundations were formed in line with the literature reviews and the data gained. In the second stage, construction firms were identified and surveys were designed. In the last stage, the information and data obtained were arranged and analyzed, and the results and recommendations were presented.

With in the scope of the survey, 31 questions were asked to the contractor company authorities under the headings of landscape projects, landscape applications, economic dimension of landscape and experiences. Four of the questions were open-ended and the others were five-choice (likert scale) multiple choice. All contractor companies affiliated to Konya Contractors Association were accepted as universe size and the sampling size was calculated as 97 with $95 \%$ confidence interval and 0.05 error margin (Newbold,1995). The survey was conducted through face-to-face interviews with 97 contractor company officials.

The data obtained from the survey forms were first edited in Microsoft Office Excel software and then transferred to SPSS 22 statistical software and analyzed. Frequencies of multiple-choice questions were removed and open-ended questions were analyzed and their common points were reflected in the findings and recommendations. The research findings were discussed and suggestions were made for housing contractors, landscape architects, architects and occupational groups and organizations in the sector.

\section{Results and Discussion}

\subsection{Results for Landscape Projects}

In the case of Konya, 97 contractor company officials were asked about their approach to constructing a landscape project: 8 people neutral, 41 people positive and 48 people stated that they strongly positive (Figure 2 ). The housing projects of the contractor firms continue to respond to many demands in today's conditions. One of these works within the scope of housing projects is landscape. Landscaping is not only an application but also an element that needs to be designed. The contractor companies are aware of this and they give an opinion about the construction of landscape projects with a very high rate.

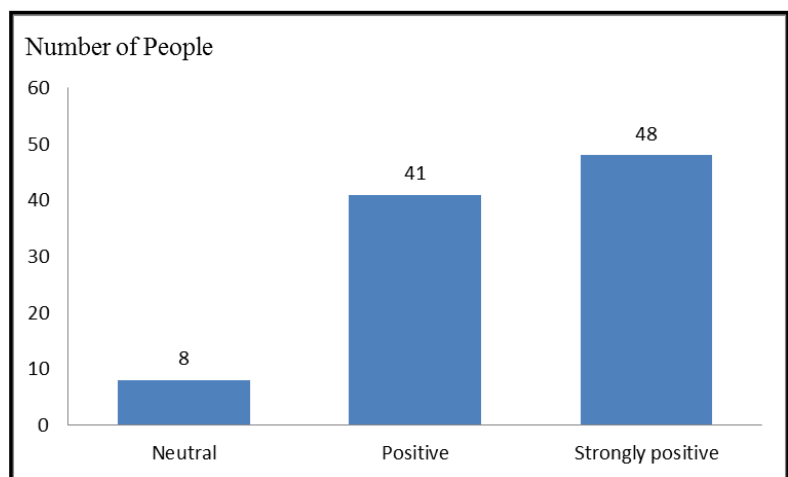

Figure 2

Contractor firms approaches to landscape design

In the questionnaire posed to the contractor firm authorities regarding the perception of the contractor firms from different occupational groups that a landscape project was carried out; 46 people positive, 10 people strongly positive, marking their options reveals that landscape projects are done by different professional groups (Figure 3). In order to change this table in the coming period, these sensations of the contractor companies should not be ignored and the necessary arrangements and precautions should be taken by professional organizations, chambers and municipalities by evaluating the results.

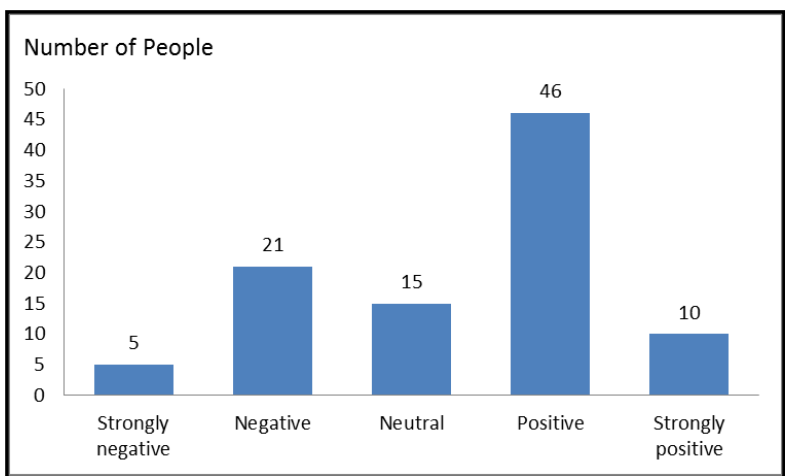

Figure 3

Contractor firms from different professional groups have heard about the landscape project

It is seen that the normal option is given by 40 people in the answers of the question about the possibilities of the contractor company authorities to reach the 
landscape architect in their landscape project requests (Figure 4). In recent years, the increasing popularity of landscape architecture has become a sought-after profession in demanding contractors. However, market conditions cause the number of landscape offices to be limited. For this reason, employment problems arise for landscape architects and there is not much demand and opportunity to reach landscape architects without commercial identity.

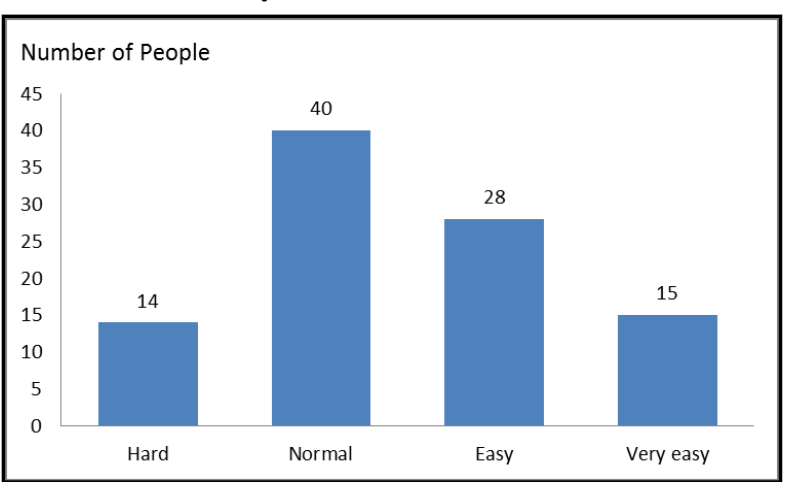

Figure 4

Opportunities for contractor firms to reach landscape architects for landscape project requests

Within the scope of the survey, when the results of the landscape projects undertaken by the contractor company officials within the scope of housing projects are examined; 19 people never, 52 people between 1-5, 13 people between $5-10,5$ people between $10-20,8$ people stated that they have built more than 20 landscape projects (Figure 5). It is foreseen as a result of the bilateral communications established during the survey that the contractor firms will have more landscape projects done in the future. The major contributors to this are the municipalities that license the constructions, the ministry of environment and urbanism, conscious housing customers and qualified contractor firms.

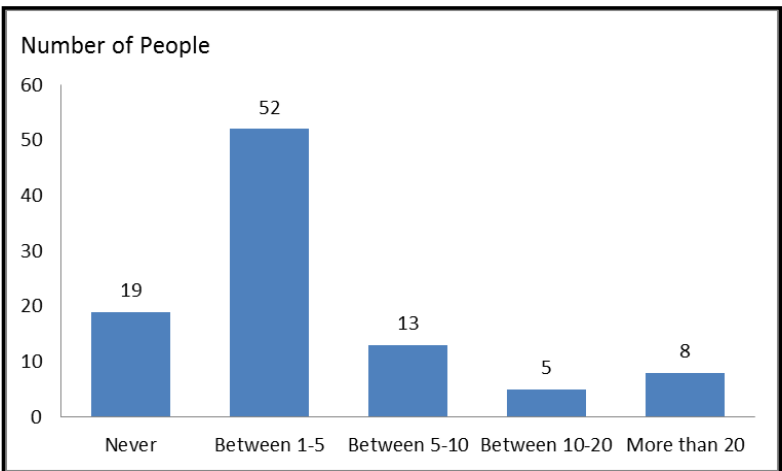

Figure 5

Number of landscape projects undertaken by contractor companies within the scope of housing projects

When asked the opinions of the contractor company authorities about the quality of the landscape projects carried out in the market, 2 people are very unqualified, 20 people are unqualified, 57 people are normal, 14 people are qualified, and 4 people expressed their opinions as highly qualified (Figure 6). Landscape projects in the market are carried out as much as possible with the wishes and the customers. However, when designing landscape projects, they are also designed by various occupational groups without conforming to certain standards. This standard is foreseen by the contractor companies during the survey process, which will not occur if the municipalities do not want landscape projects in the construction license. Looking at this result, landscape projects in the market can not be said to be highly qualified. The most important responsibilities here are the landscape architects.

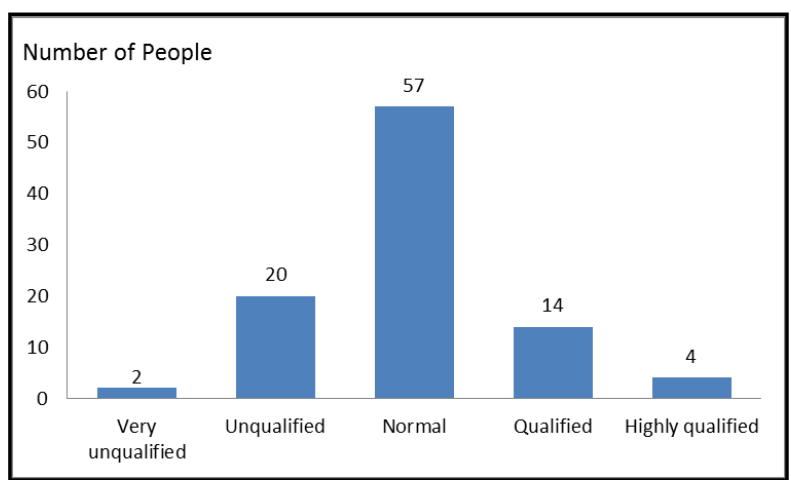

Figure 6

The opinions of the contractor firms about the quality of landscape projects in the market

Looking at the responses to the contribution of landscape projects to the promotional materials of housing projects, 6 officials think that landscape projects do not have any impact, but a large majority do (Figure 7). The main purpose of the contractor firms is to sell the houses they produce in the most profitable economic conditions. So much so that publicity and advertising play a very active role in the sales of today's houses. Houses are sometimes sold from models, sometimes from models, catalogs and even architectural projects. The contractor companies are aware of this and try to use landscape elements as efficiently as possible in their projects.

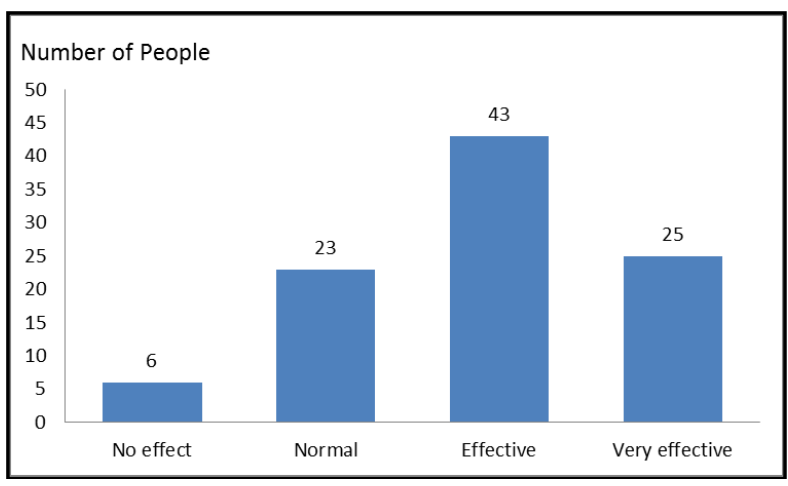

Figure 7

Contribution of landscape projects to the promotional materials of housing projects

According to the responses of the contractor company officials about the request of the construction projects of the landscape projects, 12 people strongly negative, 23 people negative, 16 people neutral, 34 people positive and 12 people have expressed their opinion are strongly positive (Figure 8). Municipalities in the process of buying residential buildings construc- 
tion permits; They require the architectural project of the architect, the static project of the civil engineer, the mechanical project of the mechanical engineer, the electrical project of the electrical engineer, the ground survey report prepared by the geological engineer and the application projects of the map engineer. In addition to all these, after the necessary documents are issued, a construction license is given with the building inspection. All these desired projects and documents are submitted to the municipality in a complete manner and it is committed to the municipality where these procedures will be implemented in accordance with the requirements. After the completion of the construction, the municipal authorities supervise the applications and grant a residence permit to these buildings. However, any landscape architect's landscape project is not requested by the municipalities at any stage. For this reason, many buildings in the market are built without any landscape projects; Landscape projects are sometimes carried out by landscape architects and sometimes by different occupational groups without any supervision concerns. This situation is visually and functionally encountered in housing landscapes with various negativities. Even though the landscape projects requested by the municipalities after having passed the number of independent sections with the recent legal regulations have found their place in the positive parcels of high numbers, it is still worrying that the landscape projects cannot find a place in the construction licenses granted by the municipalities in all housing projects.

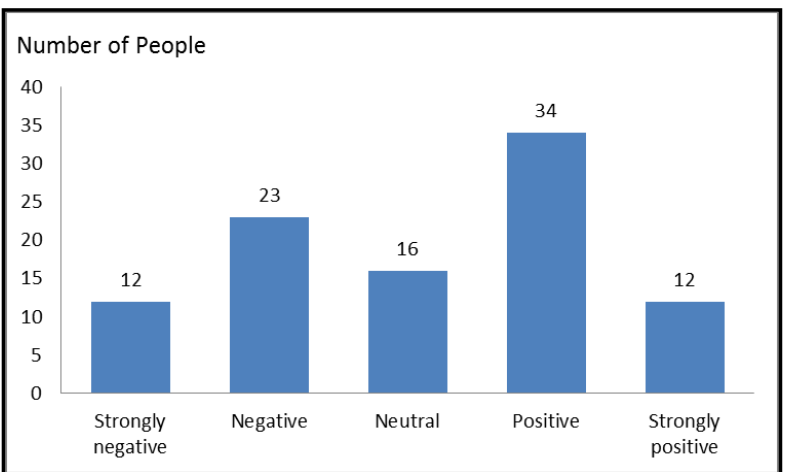

Figure 8

The opinions of the contractor companies about requesting the construction projects of the landscape projects

\subsection{Results for Landscape Applications}

When the Contractor raises questions within the scope of the opinions of the authorities on the necessity of landscape applications within the scope of housing projects; 2 people negative, 7 people neutral, 49 people positive, 39 people strongly positive (Figure 9). The contractor firms that compete with each other in housing sales are exposed to a wide variety of structural and plant applications in landscape applications. As can be seen from the results of the survey, contractor companies are quite aware of the necessity of landscape ap- plications. However, during the survey period, the contractor firms we interviewed expressed their complaints that the landscaping applications they had made within the scope of the housing projects were not carried out properly in the later processes.

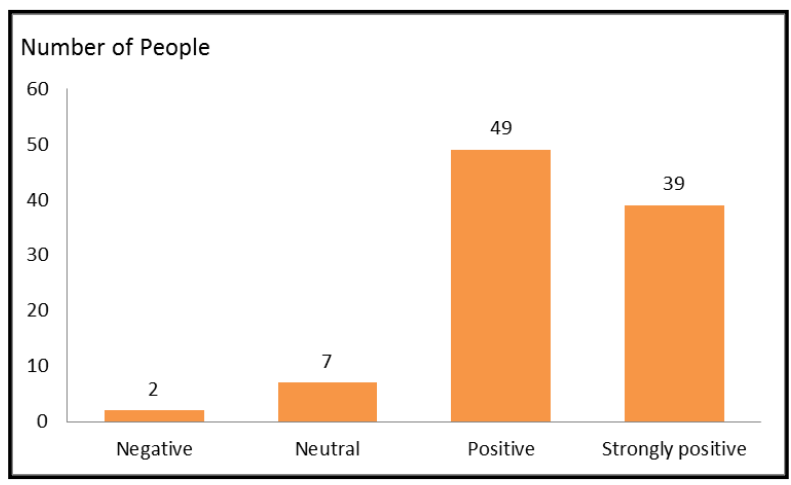

Figure 9

The opinions of contractor firms about the necessity of landscape applications within the scope of housing projects

Within the scope of housing projects, according to the answers given to the question about the occupational groups which the contractor company authorities have made the landscape applications; 44 people are landscape architects, 8 people are interior designers, 19 people are architects, 3 people are urban planners and 23 people are selected as other (Figure 10). Professional hands are needed to create accurate and qualified landscape areas. Although the contractor firms often make the landscape architects work with the landscape architect, the site supervisors he works with are involved in the landscape applications.

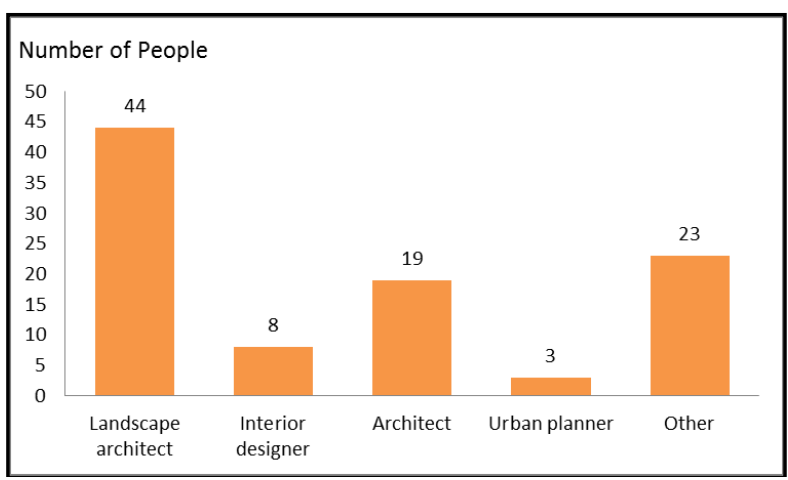

Figure 10

Professional groups in which the contractor firms have built landscape applications within the scope of housing projects

When asked about the opinions of the contractor firms about the implementation of landscape applications by a landscape architect, 5 people negative, 21 people neutral, 48 people positive and 23 people stated strongly positive (Figure 11). The results clearly show the awareness of contractor firms towards the landscape architecture profession. 


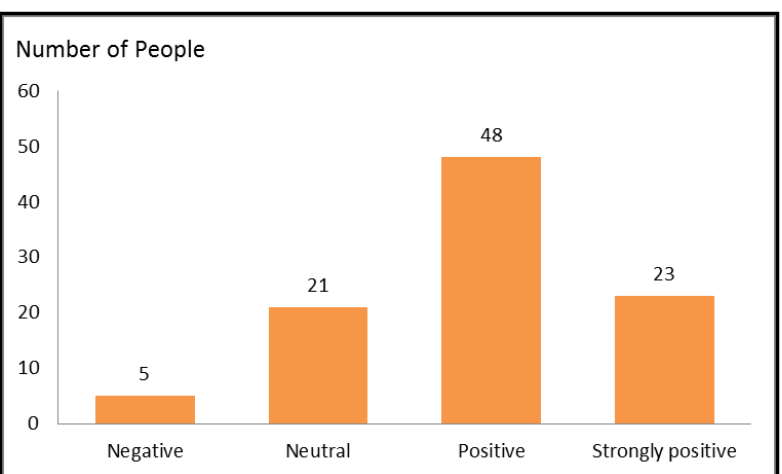

Figure 11

The opinions of the contractor firms about the implementation of landscape applications by a landscape architect

In the survey conducted on the quality of landscape practices in the sample of Konya, 97 contractor firms were asked, 4 of them were very unqualified, 23 were unqualified, 52 were normal and 18 were qualified (Figure 12). According to this result, it cannot be said that residential landscapes are qualified within the scope of Konya Province. Based on the nature of landscape applications, it is possible to say that the only factor here is not the contractor company. Landscape projectors and subcontractors, which are the other factors in practice, also share in the quality of landscape applications.

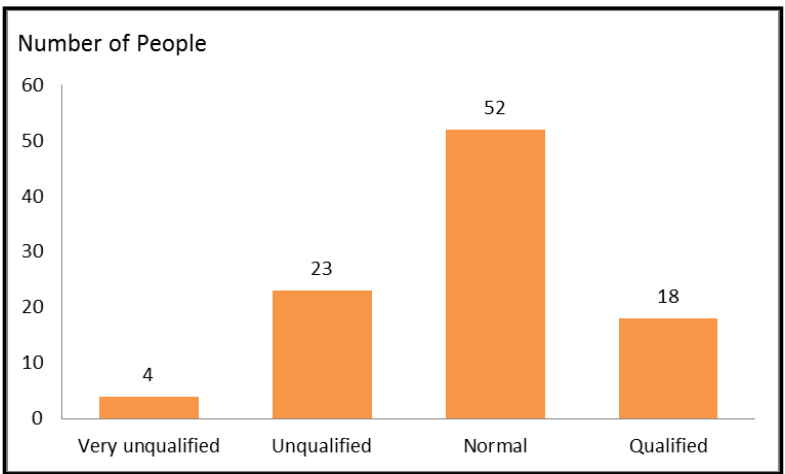

Figure 12

The opinions of the contractor companies about the quality of the landscape applications in the market

In the survey conducted in the sample of Konya province, in the survey conducted with 97 contractor company officials, 4 people never effective, 9 people stated that they were connected to landscape projects in landscaping applications at low level, 39 people at medium level, 39 people at high level and 6 people at very high level landscape applications (Figure 13). It is not very accurate to distinguish between project and application within the concept of landscape. In order to complete and correct the landscape application, a landscape architect must first make a landscape project. One of the reasons for not adhering to the landscape project in landscape applications is finance. Landscape applications, which come to the end of construction works, are one of the items that suffer most from this negativity when the financial resources of the contractor companies are exhausted. High budget plants and structural landscape elements are being replaced by their more economical counterparts. Another point is that landscape projects are not feasible.

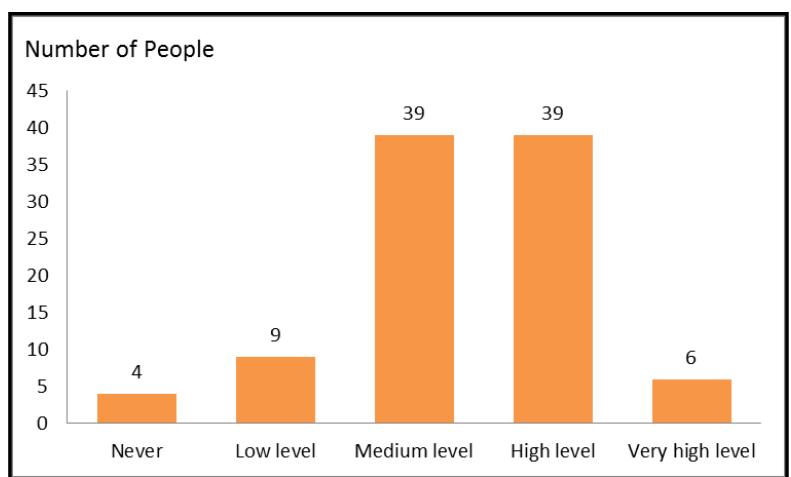

Figure 13

The level of commitment of the contractor firms to landscape projects in landscape applications

According to the answers given to the opinions of the contractor firms about the effectiveness of the landscape architect in the construction of the structural elements of the residential landscape; 2 people were never effective, 11 were low, 46 were moderate, 35 were high, 3 were very high (Figure 14). Landscape architects are obliged to design landscape areas as well as plant elements as well as structural elements. Solving these two elements in a qualified way is one of the main duties of landscape architects in their projects. A landscape architect should play an active role especially in plant applications.

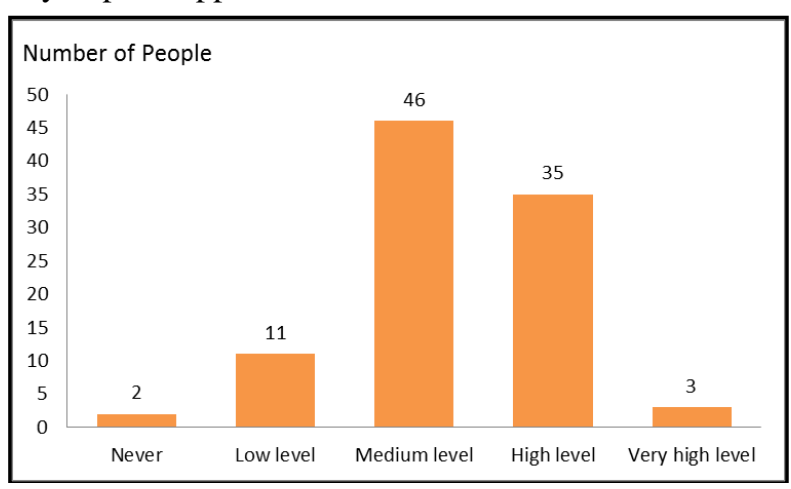

Figure 14

The opinions of the contractor firms about the effectiveness of the landscape architect in the construction of structural elements of the residential landscape

According to the answers given to the survey question which includes the opinions of the contractor firms about the effectiveness of the landscape architect on the residential landscape planting activities; 10 people were low, 42 were moderate, 40 were high, 5 were very high (Figure 15). Since the plants, which are the basic principles of residential landscape areas, are a living entity, species selection and plantation should be done with care. The landscape architect plays an active role from the project drawing stage to the application of the plant to the soil. Another important issue is to determine the characteristics of plants well. 


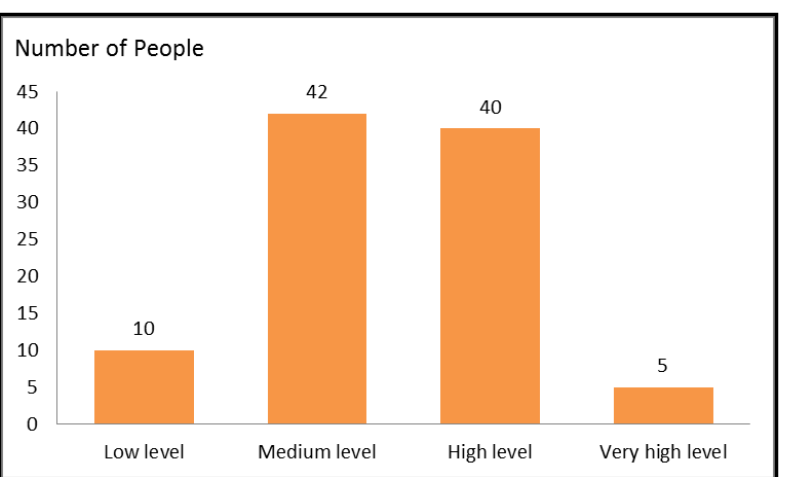

Figure 15

The opinions of the contractor firms about the effectiveness of the landscape architect on the residential landscape planting works

According to the opinions of the contractor companies in terms of their level of taking into consideration the characteristics of plant materials used in landscape applications; 2 people did not take into account at all, 10 people at low level, 33 people at medium level, 41 people at high level, 11 people stated that very high level (Figure 16). It is very important to consider the length and volume of plant materials used in landscape applications to reach their mature ages. It is seen that more than half of the contractor firms take this element into consideration. Sustainability of qualified landscapes requires to be valid not only in today's conditions but also in future periods.

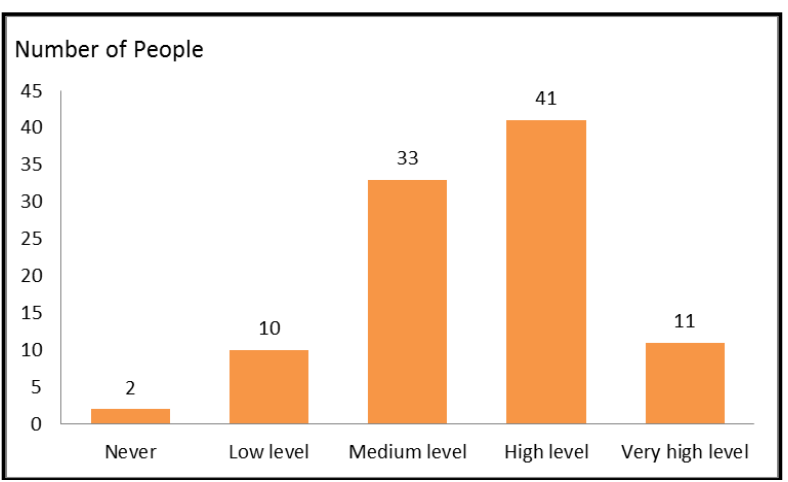

Figure 16

The level of consideration of the characteristics of plant materials used in landscape applications by contractor companies

The opinions of the contractor firms on the effectiveness of independent department sizes in landscape applications were revealed that 4 people did not affect at all, 12 people at low level, 49 people at medium level, 25 people at high level and 7 people at very high level (Figure 17). Assuming that user profiles are the most important factor in qualified residential landscape areas, it is possible for independent section sizes to affect landscaping applications, even indirectly. When this situation is taken as a basis, it is mainly at the moderate levels that the independent section sizes affect the landscaping applications in the houses constructed by the contractor firms in Konya. This shows that the mold projects are being implemented with small changes in many residential areas.

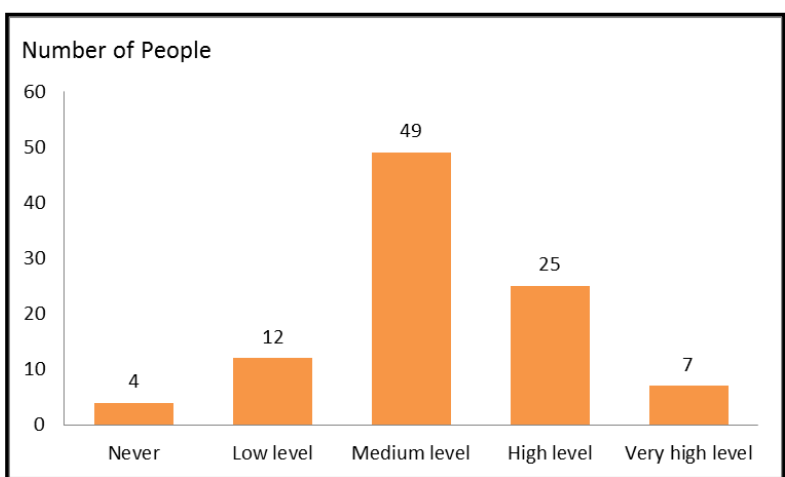

Figure 17

The opinions of the contractor firms on the effectiveness of independent department sizes in landscape applications

\subsection{Economic Evaluations}

When 97 contractor company officials were asked about the effectiveness of landscape in housing prices in Konya, 4 people had no effect, 13 people had low level, 31 people had medium level, 40 people had high level and 9 people had very high effect (Figure 18). The biggest purpose of the contractor companies in housing production is to sell the houses they produce at the prices they want. The difference that the landscape adds to the structures with its plant and structural qualities is one of the leading reasons that attract customers.

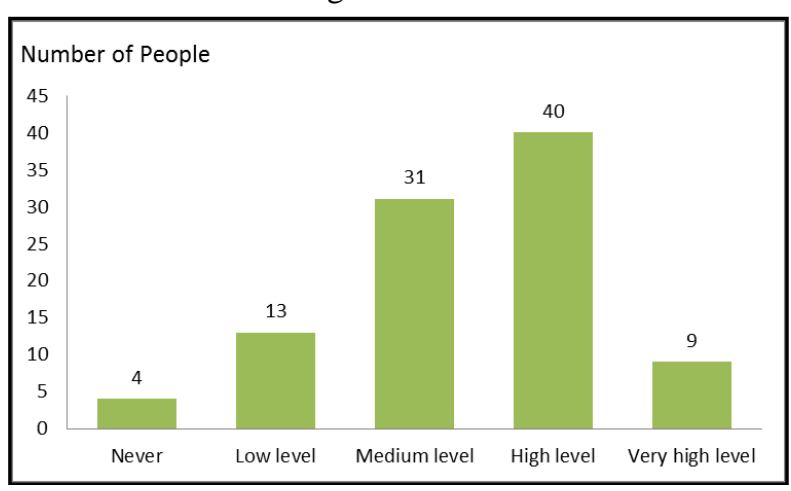

Figure 18

The opinions of the contractor firms on the effectiveness of landscape in housing prices

In the survey conducted in the Konya province, when asked to take into account the landscape costs in the cost analysis conducted before the contractor companies, 5 people were never present, 19 people were considered low, 41 people were considered medium level, 29 people were considered high level and 3 people were considered very high level (Figure 19). Housing prices need to be determined by various cost analyzes before they start work. This cost analysis is to collect various items of construction and calculate them with different methods. Considering the effect of landscaping on sales, it is quite possible to create a landscaping area in residential parcels.

These landscape areas should be put into the costs before starting the construction work. Cost analysis that is not well done either causes contractor firms to be damaged or requires certain items to be waived. 
Landscape, which is one of the last items in terms of construction techniques, is the factor that receives the most from these negative situations.

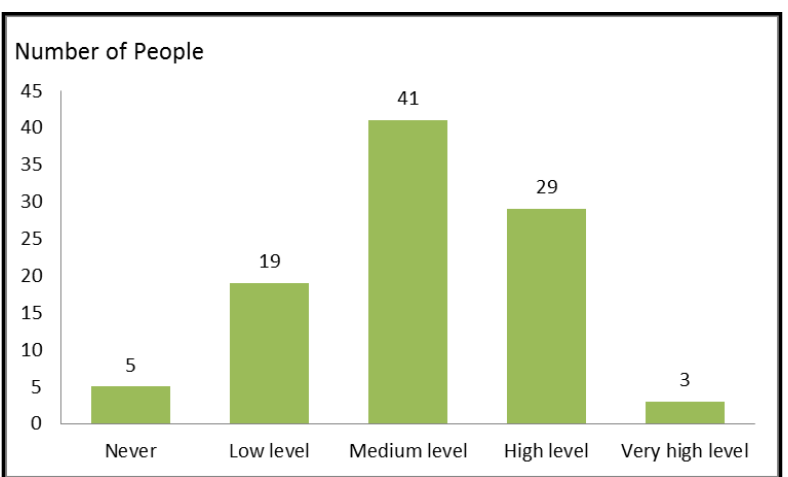

Figure 19

The degree of consideration of landscape costs in the cost analysis of the contractor firms before starting work

Considering the situation regarding the budget levels allocated by the contractor firms for landscape projects; 3 people did not allocate at all, 15 people at low level, 69 people at medium level, 9 people at high level, 1 person stated that they have a very high level budget (Figure 20). Necessary budgets are allocated for landscape projects in high number of residential works with high return and profit rates. According to this result, the contractor firms do landscape projects with moderate budgets without spending much money. Assuming that cost and prices are the focal point, it is important that contractor firms are able to produce quality jobs with moderate budgets.

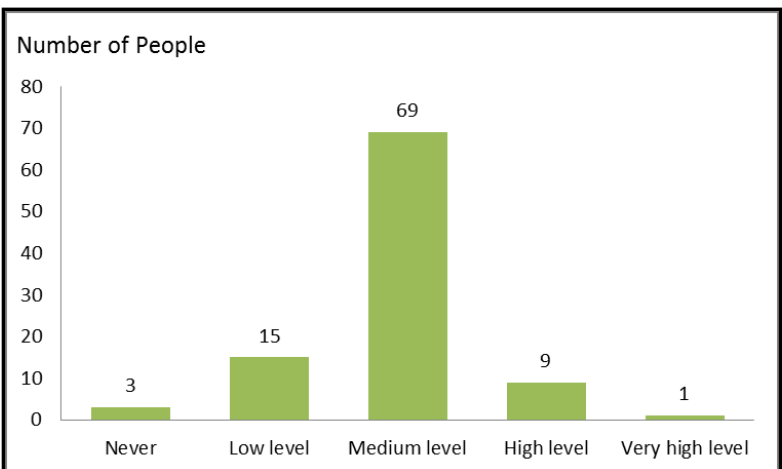

Figure 20

Budget levels allocated by contractor firms for landscape projects

In the survey conducted in Konya province, when asked the contractor firms about the budget levels allocated for landscaping applications in accordance with standards, they stated that 1 person did not allocate at all, 14 persons at low level, 67 persons at middle level, 14 people at high level and 1 person at very high level (Figure 21). In this case, contractor companies generally prefer to allocate a medium level budget in landscape applications according to the standards. Contractor companies are mostly aiming to do a lot of work with low cost. This is one of the most important factors in every stage of construction, not only in the landscape area. However, although cheap labor and materials provide economic advantages to the contractor in the short term, repairs and alterations due to cheap materials and labor in later periods create negative effects both for the housing users and the contractor companies.

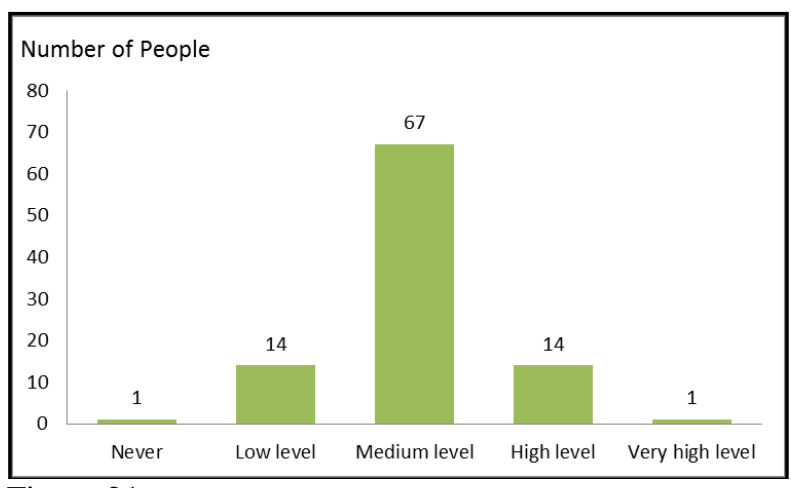

Figure 21

Budget levels allocated by contractor companies for landscape applications in accordance with standards

According to the answers of the questionnaire related to the level of taking into account the price relationship between the characteristics of plant materials (height, body thickness, appearance, root condition); 3 people do not take into account at all, 10 people at low level, 54 people at medium level, 26 people at high level, 4 people stated that very high level (Figure 22). Plants that are bulky in size and showy are always remarkable. However, these plants are more costly than plants of less volume and size. This value is determined by the age of the plant and the maintenance effect given up to that year. Contractor companies want to use quite showy and tall plants in the gardens of their houses. However, in view of cost and finance, this is often not possible. Although this difference is economically beneficial to contractor firms, it causes a lot of loss to the land users in terms of landscaping until they reach the standards of the plants.

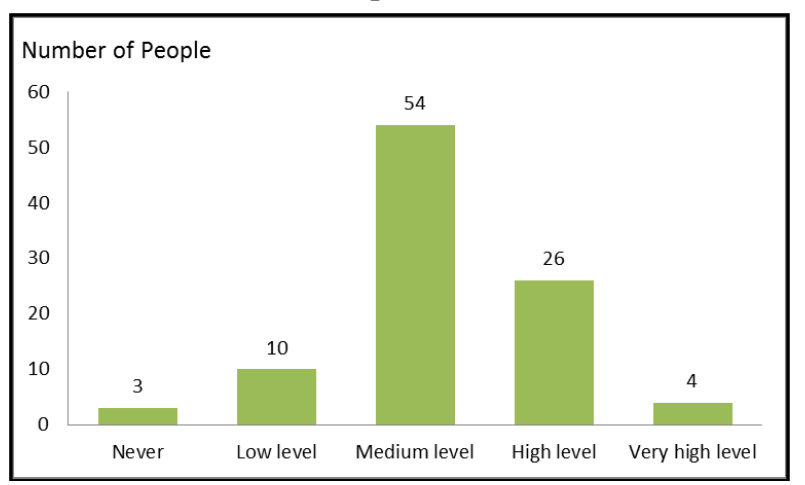

Figure 22

The level of the contractor firms to consider the relationship between the quality and price of plant materials

When asked the contractor firms the level of consideration of the quality of structural materials and price relations, 9 of them stated that they considered low level, 48 of them considered medium level, 36 of them considered high level and 4 of them considered very high level (Figure 23). The diversity in structural materials eliminates uniformity in landscape applica- 
tions and projects. Providing a wide range of products to their customers, suppliers strengthen the hands of project architects and implementers. Concrete, wood and metal-containing materials are used in many structural areas of the landscape. Raw materials of this structure are processed and various landscape elements such as floor coverings, lighting, garden furniture, pergola and bench are created. These elements determine the type of material used, the design, the workmanship and the prices of the raw material products. At the same time, whether domestic or imported production is an important role in price. Contractors want to use these structural elements according to the housing classes they produce. Based on this result, the level of taking into account the relationship between the quality of the structural materials and the price shows a moderate and high tendency.

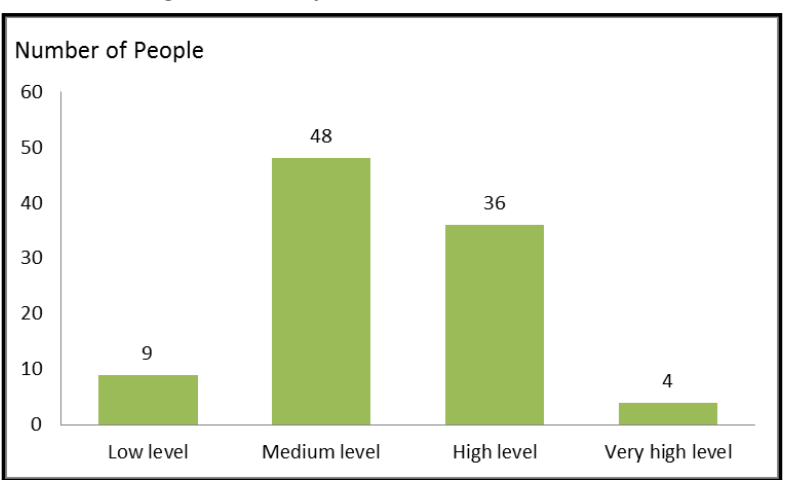

Figure 23

Contractor firms level of consideration of the relationship between the quality of structural materials and price

When asked the contractor firms about the contribution of landscape projects in housing sales; 2 people have no contribution, 5 people low contribution, 27 people normal, 43 people contribution, 20 people have stated that high contribution (Figure 24). Landscape projects affect housing sales in many ways. These effects are seen both in the pre-sales promotional cata$\log$ brochure signs and at the end of the construction. As it can be seen from the results of the survey, contractor firms believe in the contribution of landscape projects in housing sales.

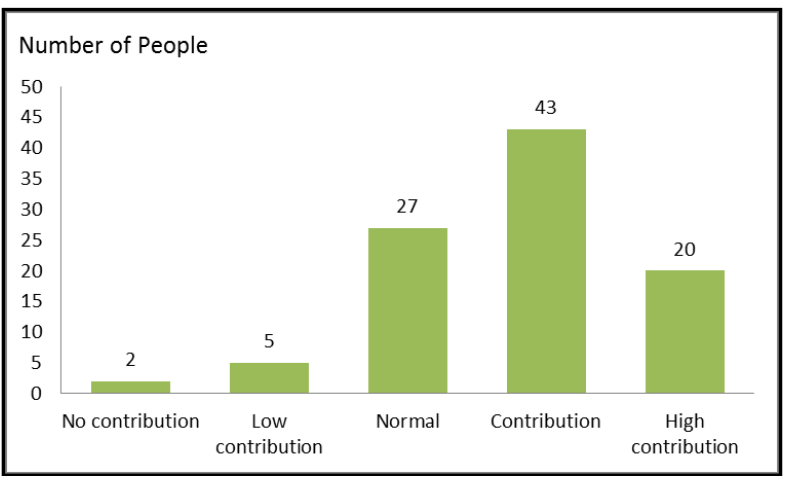

Figure 24

The opinions of the contractor firms on the contribution of landscape projects in housing sales
When asked about the contribution of the landscaping applications to the housing sales of the contractor companies; 2 people have no contribution, 5 people low contribution, 33 people have normal, 39 people contribution, 18 people have stated that high contribution (Figure 25). The landscape areas add a lot of quality to the houses but make the houses complex structures where children can play outside, families go out and spend time in the garden areas and even relieve the stress of the day in the sports fields. As can be seen from this result, the contribution of landscape applications to housing sales is quite high. It is accepted that one of the building blocks of qualified houses is landscaping.

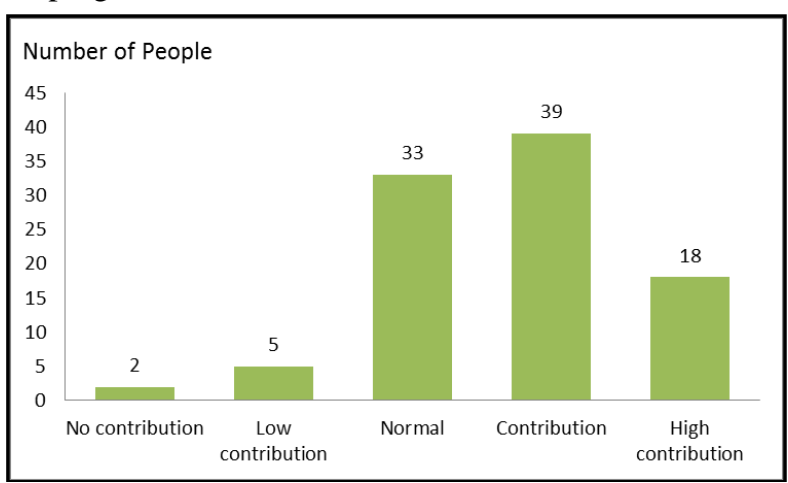

Figure 25

The opinions of the contractor firms on the contribution of landscaping applications in housing sales

\subsection{Evaluation Based on Experience}

When the satisfaction levels of the landscape projects undertaken by the contractor companies are examined, it is observed that 1 person is not satisfied at all, 15 people are at low level, 45 people are at medium level, 35 people are at high level and 1 person is at very high level (Figure 26). According to this result, it is observed that contractor companies are mostly satisfied with the projects they have commissioned.

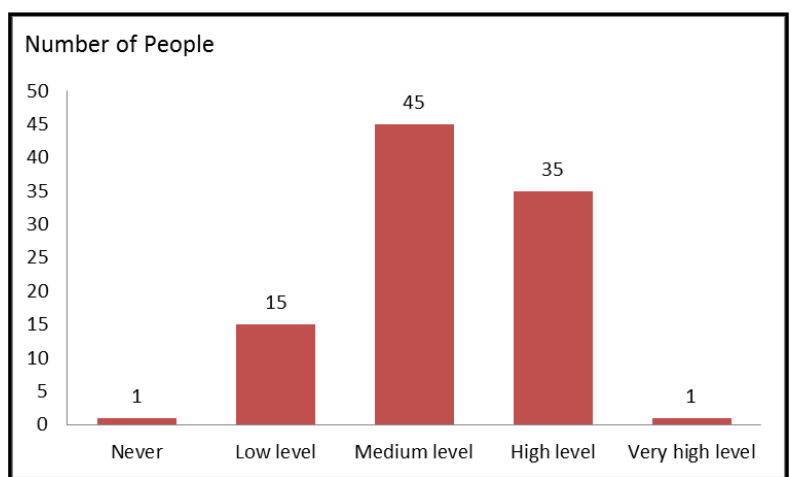

Figure 26

Satisfaction levels of landscape projects undertaken by contractor companies

When the satisfaction levels of the contractor firms for landscape applications are examined; 1 person was not satisfied at all, 12 people were at low level, 49 people were at medium level, 33 people were at high level, 2 people were at a very high level of satisfaction (Figure 27). According to this result, it is seen that the 
contractor firms are satisfied with the landscaping applications at a moderate level.

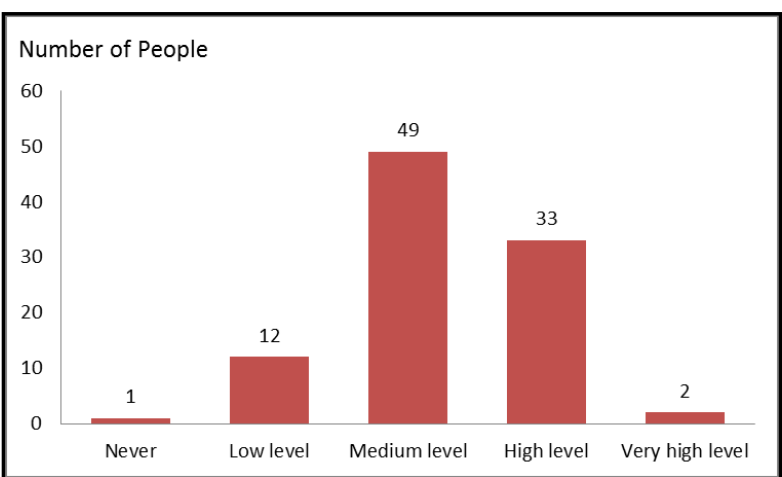

Figure 27

Satisfaction levels of the contractor firms for landscape applications

Satisfaction levels of the customers regarding the residential landscape of the contractor firms were found to be 2 people not satisfied at all, 7 people at low level, 38 people at medium level, 45 people at high level and 5 people at very high level (Figure 28). The housing sector, which has developed quite recently, increases the demands and expectations expected from the residence. However, the concept of satisfaction in contracting markets is very important for contractor companies. According to this result, it shows that contractor companies are highly satisfied with the landscape of their customers within the scope of housing projects.

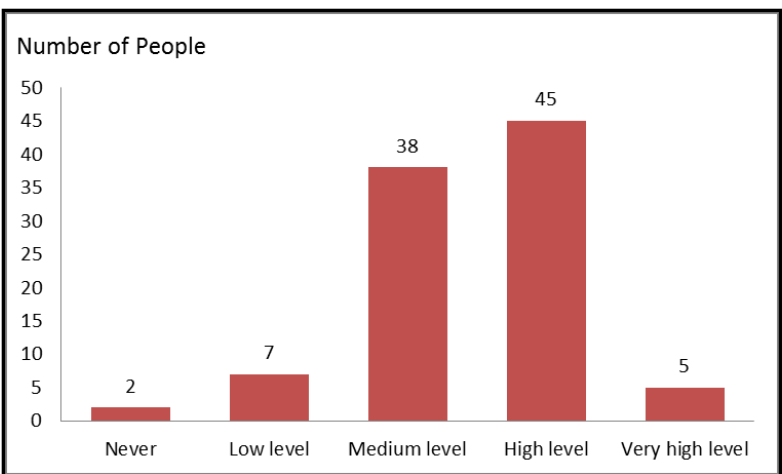

Figure 28

Satisfaction levels of customers related to residential landscape by contractor firms

When asked about the applicability percentages of the landscape projects of the contractors; 3 people were between 0-20\%, 17 people were between 20-40\%, 27 people were between $40-60 \%$, 32 people were between $60-80 \%$, and 18 people were between $80-100 \%$ (Figure 29). According to this result, the applicability of the landscape projects commissioned by the contractor firms shows a high tendency. It is reported that the landscape projects cannot be implemented in the options where the result is low, and the contractor companies cannot get the efficiency from the landscape projects they pay a certain price.

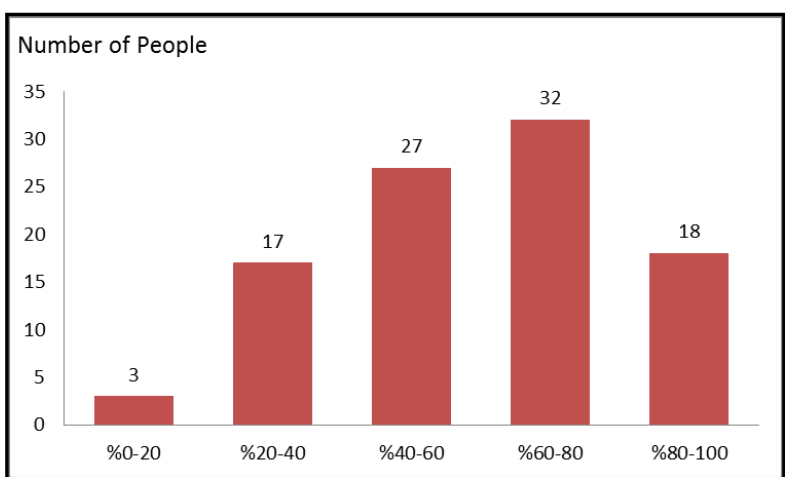

Figure 29

Applicability levels of landscape projects undertaken by contractors

\section{Conclusion and Suggestion}

The contractor firms have generally positive approaches to landscape projects within the scope of housing projects. This shows that the existence of landscape projects within the scope of housing projects will be seen more. Landscape projects are not considered in housing projects in most cases because they are not legally required. Therefore, a landscape architect is not needed for landscape projects under market conditions. This situation confirms the sensations that different professional groups of contractor firms are also doing landscape projects.

As it is seen in the survey, when the quality of the landscape projects of the contractor firms is asked, the landscape projects in the market are not considered sufficient in terms of quality. Landscape projects are not required in the construction permits issued by the municipalities unless the housing independent sections exceed a certain number. The negative effects of this situation mostly affect landscape architects and residential users. Projects carried out outside a certain authority often remain as non-feasible drawings, which are analyzed in unqualified complexities. Although a certain part of the contractor companies is aware of this and foresee that the landscape projects be requested by the municipalities, a certain part does not want to deal with the municipalities during the construction license stage of the landscape projects.

Landscape architects should transfer their acquired knowledge and experience to their work. Aware of the gains it brings, the contractor firms think that landscape architects have a high level of efficiency in residential landscape structural elements. Companies that do not have sufficient experience and awareness about this issue think negatively.

Plant elements in landscape applications require more knowledge and experience than structural elements. Professional discipline in this field is landscape architecture. The contractor companies, which are aware of this, see the impact of landscape architects at high levels in the planting of residential landscape. Since plants are a living entity, they show different developments after planting. Therefore, plants should 
be planted according to the height and volume they will receive in the future. This issue is very important in landscape applications. Although some of the contractors that are aware of this issue pay attention to this element, this awareness is not seen much in practice yet.

Landscape has a direct impact on house sales prices within the scope of the quality it provides to the housing. The contractors that are aware of this place give the necessary importance to the landscape within the scope of housing projects.

Although landscape is now being implemented within the scope of most housing projects, it is not at the forefront of the cost of contractor companies in the cost analyzes made before starting work. In terms of construction techniques, landscape, which is implemented in the last stages, can bring extra burden to the contractor companies if the cost calculations are not done correctly. The budgets allocated for the landscape projects by the contractor firms remain at the middle and lower levels. The contractor firms that allocate middle and lower budgets for landscape projects follow the same path in landscape applications. Considering the contribution of landscape to house sales and prices, it is seen that the budgets allocated to projects and applications are insufficient.

Landscape applications have a direct contribution to housing sales. In today's conditions, landscape has an important place within the scope of housing projects. The contractor companies, which are aware of this, are one step ahead of their competitors with their landscape applications.

The contractor companies are satisfied with the landscape projects they have commissioned at medium and high levels. Here, it is important that contractor companies do not have their landscape projects completely done to landscape architects. Contractor companies are generally satisfied with medium and high levels in landscape applications as in landscape projects.

Many professional groups close to landscape architecture keep these works in their fields of activity. It is not right for individuals and legal persons who have not received training and experience who have not been trained in a job to do these works. Landscape architects should be more effective and have a say in the market share. Local authorities, professional chambers, universities and most importantly landscape architects have a great duty to do this

As a result of the survey conducted with contractor firms in Konya, it is seen that landscape architects are not so easily reached. Considering that the cake share is also limited, landscape architects in the market need to increase their accessibility.

The quality of the landscape projects and implementations in the market should be increased. The easiest and simplest way to increase this is by subcontracting contractors' landscape projects to skilled landscape architects.
Within the scope of obtaining construction permits by local authorities, landscape projects must be requested. Even if municipalities want landscape projects up to a certain number of independent departments, it is absolutely necessary to request these projects in all residences within the scope of housing projects. When this requirement is fulfilled, since the landscape architects will sign the landscape projects, the contractor firms' working rates with the landscape architects will also increase substantially.

The activities of landscape architects on plant and structural materials and implementation of a landscape application by the landscape architect should be explained to the contractor companies in detail. When contractor firms realize the importance of working with landscape architects, they will inevitably see positive results in their work.

Contractors mostly want to reduce the cost of their landscape applications within the scope of housing projects. However, in some cases, the quality decreases while the cost decreases. Decreasing quality means going beyond the standards in landscape applications. This is especially the case with herbal elements. The contractor companies prefer small plants in their applications because of their favorable prices. While preferring these particular plants, they often sow the plants without considering the height and volume they will receive in future periods. In order to prevent this situation, the necessary institutions, organizations, professional chambers and local administrations should be given training to the contractor companies.

With this research, it has been determined that the approaches of the contractor companies towards landscape projects and applications are positive. This result shows that landscape works in the housing sector will progress rapidly in terms of quality and quantity in the coming years.

\section{References}

Bayraktar E (2007). Bir İnsanlık Hakkı Konut, İstanbul, Boyut Yayıncilık, p.

Broto C (2000). Residential Architecture, Barcelona, p. 9.

Carr S, Francis M, Rivlin LG, Stone AM (1992). Public Space, New York, Cambridge University Press, p.

Chiesura A (2004). The role of urban parks for the sustainable city, Landscape and Urban Planning, 68 (1), 129-138.

Çınar S (2008). Ev Bahçesinde Peyzaj Tasarımı Süreci, İstanbul Üniversitesi Orman Fakültesi Dergisi, 58 (1), 73-90.

Edwards B, Sibley M, Hakmi M, Land P (2005). Courtyard Housing, New York, Taylor \& Francis, p. 297.

Gül A, Küçük V (2001). Kentsel Açik-Yeşil Alanlar Ve Isparta Kenti Örneğinde İrdelenmesi, Süleyman 
Demirel Üniversitesi Orman Fakültesi Dergisi, 2, 27-48.

Gül G, 2012, gayrimenkul yatırımcısı inşaat firmalarında konut pazarlama yönetimi süreci, Yüksek Lisans, İstanbul Teknik Üniversitesi, İstanbul.

Keleş R (2008). Kentleşme politikası. Ankara, İmge Kitabevi, p.

Kırgızoğlu MI (1995), Peyzaj Kavramı ve Şehir Planlamasında Kullanımı, Erzurum, Atatürk Üniversitesi Ziraat Fakültesi, p. 1.

Newbold P (1995). Statistics for Business and Economics. Prentice-Hall International, New Jersey, $867 \mathrm{p}$.

Per AF, Mozas J, Ollero AS (2013). 10 Stories of Collective Housing, Spain, a+t architecture publishers, p.
Polat AT, Önder S (2012). Kentsel Peyzaj: Tasarım Ve Uygulamaya Yönelik Bazı Öneriler, Kentsel Peyzaj Alanlarının Oluşumu ve Bakım Esasları Semineri, 97-116.

Sherer PM (2003). Why America Needs More City Parks and Open Space, The Trust For Public Land, $1-32$.

Şişman EE, Korkut AB, Etli B (2008). Tekirdağ Valiliği Tören ve Park Alanı Peyzaj Tasarım Süreci, Tekirdağ Ziraat Fakültesi Dergisi, 5 (2), 119129.

Smith C, Clayden A, Dunnett N (2008). Residential Landscape Sustainability, United Kingdom, Blackwell Publishing, p. 4.

Song S, Fang C, Li R, Gao A (2011). Residential Landscape, China, Liaoning Science\&Technology Publishing Hause, p. 